\title{
DOUBLE MOVEMENTS DALAM TAFSIR AL-MISHBAH
}

\author{
Rahmi dan Novizal Wendry \\ UIN Imam Bonjol Padang \\ Jl. Mahmud Yunus Lubuk Lintah Padang, \\ Email: rahmimag@uinib.ac.id novizalwendry@uinib.ac.id
}

\begin{abstract}
This article discusses Fazlur Rahman's double movement hermeneutic theory in interpreting the Quran. Some parties accept it while some others tend to reject. This article focuses on tracing the attitude and the application of M. Quraish Shihab toward the double movement in the interpretation of the Quran, by using content analysis. The material object of this research is Shihab's interpretation on the law verses contained in Tafsir Al-Mishbah, where Rahman also discusses them in his book. Shihab accepts hermeneutic double movement as a method in interpreting the Quran. However, obligations are; not ignoring the text of the verses, does not lead to the elimination of the law that already exists in Quran, by paying attention to the verses as a whole, do not try to understand it in pieces. Shihab rejects the use of hermeneutics in interpreting the Qur'an if these rules are ignored. Based on these principles, i found two model of Shihab's application. Among the four verses which were traced in this study; Shihab uses double movement to interpret two verses, and the other two are interpreted without using double movement.
\end{abstract}

Keywords:

Hermeneutic, Double Movement; Fazlur Rahman; M Quraish Shihab; Tafsir Al-Mishbah.

\section{Abstrak}

Artikel ini mendiskusikan gagasan hermeneutik double movement Fazlur Rahman dalam menafsirkan Alquran. Terdapat kalangan yang menyetujui dan menolaknya. Artikel ini menfokuskan pada penelusuran terhadap sikap dan aplikasi M. Quraish Shihab terhadap double movement dengan pendekatan content analisys. Objek material riset ini adalah penafsiran Shihab terhadap ayat hukum yang terdapat dalam Tafsir Al-Mishbah, dimana Rahman juga membahas ayat tersebut. Tulisan ini menemukan bahwa secara prinsip Shihab meresepsi positif terhadap keberadaan hermeneutik double movement, dijadikan pendekatan dalam penafsiran Alquran. Namun, ada rambu yang mesti dipatuhi dalam menggunakannya yaitu dengan tidak menafikan keberadaan redaksi ayat, tidak menghapus aspek hukum yang terkandung dalam Alquran, dan memerhatikan ayat secara holistik. Shihab menolak penggunaan hermeneutik dalam menafsirkan Alquran jika batasan-batasan tersebut diabaikan. Berdasarkan prinsip tersebut, ditemukan variasi sikap Shihab. Dari keempat ayat yang ditelusuri dalam kajian ini; dua ayat ditafsirkann oleh Shihab dengan menggunakan double movement, dan dua lainnya ditafsirkannya tanpa menggunakan double movement.

Kata Kunci:

Hermeneutika, Double Movement; Fazlur Rahman; M. Quraish Shihab; Tafsir Al-Mishbah.

\section{A. PENDAHULUAN}

Salah satu aspek yang memotivasi penganut Islam menggiatkan kajian progresif terhadap Alquran adalah adanya asumsi umum bahwa pesan moral Alquran dapat beradaptasi dengan kondisi waktu dan tempat manapun. Apalagi jika dikaitkan dengan fenomena kontemporer yang jauh berbeda jika dihubungkan dengan historisitas turunnya Alquran. ${ }^{1}$

\footnotetext{
${ }^{1}$ Abdullah Saeed, Paradigma, Prinsip Dan Metode Penafsiran Kontekstualis Atas Al-Qur'an (Yogyakarta: Baitul Hikmah Press, 2015), 291.
}

Upaya kajian progresif terhadap Alquran ini antara lain dilakukan oleh tokoh seperti Hasan Hanafi, Fazlur Rahman, M Syahrur, dan Nasr Hamid Abu Zayd. Gagasan utama yang mereka gusung adalah penafsiran Alquran kontekstual dengan pendekatan hermeneutik. Pendekatan hermeneutika ini dianggap sebagai cara baru dalam memaknai Alquran, sehingga memunculkan pro dan kontra ketika digunakan terhadap Alquran. Menurut Syamsuddin dan dikuatkan juga oleh Muzayyin, terdapat tiga model resepsi kesarjanaan Alquran kontemporer terhadap hermeneutik; pertama, kelompok yang meresepsi secara totalitas, kedua, kelompok 
rejecsionist yang tidak menerima secara utuh, dan ketiga, kelompok yang moderat, dengan mengatakan bahwa sebagian teori hermeneutik dapat diterima dalam kajian keislaman. ${ }^{2}$

Alasan utama kalangan penolak dilandasi historisitas hermeneutik, bahwa teori ini lahir dalam kesarjanaan Barat yang pada awalnya digunakan untuk menafsirkan Bibel. Bagi mereka karakteristik Bibel jauh berbeda dengan Alquran karena subjektivitas dan relativitas produk tafsirnya tidak rinci dan tidak prosedural. ${ }^{3}$ Husaini misalnya berargumen bahwa penerapan hermeneutika dalam menafsirkan Alquran memunculkan kontroversi. Di antara tokoh penggusung teori ini menurut Husaini adalah Fazlur Rahman dan Amina Wadud. ${ }^{4}$

Adapun alasan utama kalangan yang menerima hermeneutik adalah agar penafsiran Alquran bisa menjadi kontekstual. Hermeneutik dianggap penting dilakukan agar tafsir atau kajian terhadap Alquran lebih kontekstual yang mampu menjawab tantangan zaman. ${ }^{5}$ Hermeneutik merupakan kebutuhan supaya perkembangan dan ranah keilmuan mufasir bisa ter-upgrade, asalkan tidak terlepas dari kaedah-kaedah tafsir yang sudah

\footnotetext{
${ }^{2}$ Sahiron Syamsuddin, "Hermeneutika Jorge J. E. Gracia Dan Kemungkinannya Dalam Pengembangan Studi Dan Penafsiran Al-Qur'an," in Upaya Integrasi Hermeneutika Dalam Kajian Qur'an Dan Hadis, Teori Dan Aplikasi (Yogyakarta: Lembaga Penelitian UIN Sunan Kalijaga, 2011), 143; Muzayyin Muzayyin, "Resepsi Hermeneutika Dalam Penafsiran Al-Qur'an Oleh M. Quraish Shihab: Upaya Negosiasi Antara Hermeneutika dan Tafsir al-Qur'anuntuk Menemukan Titik Persamaan dan Perbedaan.," Nun: Jurnal Studi Alquran dan Tafsir di Nusantara 1, no. 1 (December 28, 2015), https://doi.org/10.32459/nun.v1i1.11.

${ }^{3}$ Reflita Reflita, "Kontroversi Hermeneutika Sebagai Manhaj Tafsir (Menimbang Penggunaan Hermeneutika dalam Penafsiran al-Qur'an)," Jurnal Ushuluddin 24, no. 2 (December 10, 2016): 135-49, https://doi.org/10.24014/jush.v24i2.1625.

${ }^{4}$ Adian Husaini, Hermeneutika Dan Tafsir Alquran (Jakarta: Gema Insani, 2007), xii.

${ }^{5}$ Abdul Rasyid Ridho, "Metode Hermeneutika dan Implementasinya dalam Menafsirkan Alquran", al Burhan: Kajian Ilmu dan Pengembangan Budaya Alquran 17, No 2 , 2017, 272.
}

ada, ${ }^{6}$ sikap selektif sangat dibutuhkan; tidak menolak secara membabi buta dan tidak menerima secara keseluruhan. ${ }^{7}$ Pertanyaan selanjutnya adalah bagaimana menggunakan hermeneutik secara selektif, tidak terlepas dari kaedah tafsir; kaedah tafsir yang mana, apa batasannya, dan bagaimana contoh aplikasi penggunaan hermeneutik yang selektif tersebut?

Artikel ini memaparkan bagaimana $\mathrm{M}$. Quraish Shihab menerapkan hermeneutika yang teraplikasi dalam karya tafsirnya, Tafsir al-Mishbah. Urgensi mengungkap ini adalah karena dalam konteks Indonesia, hanya ia yang bisa dikatakan sebagai penulis tafsir 30 juz dengan latar akademik Alquran dan Tafsir. Berdasarkan investigasi penulis terdahulu, diketahui bahwa Shihab menyelesaikan pendidikan sarjana, magister, hingga doctoral dalam bidang tafsir Alquran pada Universitas Al-Azhar Kairo. Predikat yang diperolehnya adalah Summa Cum Laude, atau penghargaan Mumtaz ma'a Martabat al-Syaraf al-'Ula (Penghargaan Tingkat I). ${ }^{8}$ Ia diklaim oleh Muhammad Iqbal, sebagai doktor tafsir pertama di Asia Tenggara pada universitas Islam tertua tersebut. ${ }^{9}$

Federspiel mengklaim bahwa Shihab adalah sosok penulis, mufasir, mendapatkan kompetesi tafsir yang lebih baik daripada hampir semua penulis tafsir Indonesia lainnya. Di samping itu, tulisan-tulisan Shihab memformulasikan kaidah baru bagi kajian

${ }^{6}$ Rif'atul Khoiriah Malik, "Hermeneutika AlQur'an Dan Debat Tafsir Modern: Implementasinya Dengan Masa Kini," AT-TURAS: Jurnal Studi Keislaman 6, no. 1 (August 19, 2019): 56-76, https://doi.org/10.33650/at-turas.v6i1.583.

${ }^{7}$ Reflita, "Kontroversi Hermeneutika Sebagai Manhaj Tafsir (Menimbang Penggunaan Hermeneutika dalam Penafsiran al-Qur'an).,, 147.

${ }^{8}$ M. Djidin and Sahiron Syamsuddin, "Indonesian Interpretation of the Qur'an on Khilāfah: The Case of Quraish Shihab and Yudian Wahyudi on Qur'an, 2: 3038," Al-Jami'ah: Journal of Islamic Studies 57, no. 1 (November 26, 2019): 143-66, https://doi.org/10.14421/ajis.2019.571.\%p.

${ }^{9}$ Muhammad Iqbal, Etika Politik Qurani, Penafsiran Quraish Shihab Terhadap Ayat-Ayat Kekuasaan (Medan: IAIN Press, n.d.), 210. 
Alquran yang digunakan oleh masyarakat Indonesia. ${ }^{10}$

Sebagai seorang intelektual akademis kontemporer dan penulis tafsir di Indonesia, Shihab respons terhadap penggunaan hermeneutika dalam menafsirkan Alquran. Untuk itu, penting kiranya ditelaah secara mendalam bagaimana sikap Shihab terhadap pendekatan tersebut serta aplikasinya dalam karya monumentalnya, Tafsir Al-Mishbah. ${ }^{11}$

Di sisi lain, Rahman, sebagai penggagas teori double movement, dianggap oleh Saeed sebagai salah seorang pemikir Islam yang paling orisinil, terutama ketika mengungkap pemaknaan ayat-ayat hukum. Saeed menambahkan bahwa Rahman mampu memberikan penyelesaian penafsiran aspek hukum yang terdapat dalam Alquran sejalan dengan perkembangan zaman. ${ }^{12}$ Hal ini juga kiranya mendorong sarjana lainnya seperti seperti Abdullah Saeed, Amina Wadud, ${ }^{13}$ dan Amin Abdullah memberikan apresiasi terhadap teori double movement yang digagasnya. $^{14}$

Kajian mengenai teori double movement dan kaitannya dengan Tafsir Al-Mishbah telah disinggung oleh penelitian terdahulu. Johanna Pink antara lain seperti diungkap oleh Ikhwan memandang bahwa meskipun Shihab dalam pengantarnya menegaskan menggunakan pendekatan hermeneutika baru dalam penafsiran Alquran seperti Rahman, namun

\footnotetext{
${ }^{10}$ Howard M. Federspiel, Kajian Al-Quran Di Indonesia: Dari Mahmud Yunus Hingga Quraish Shihab (Bandung: Mizan, 1996), 295.

${ }^{11}$ Karya ini terdiri dari 15 jilid. Edisi pertama diterbitkan tahun 2000 dan edisi kedua terbit tahun 2003.

${ }^{12}$ Saeed, Paradigma, Prinsip Dan Metode Penafsiran Kontekstualis Atas Al-Qur'an, 50.

${ }^{13}$ Amina Wadud Muhsin, Wanita Di Dalam Alquran (Bandung: Pustaka, 1994), 5. Wadud dalam buku ini mengakui bahwa ia mencoba menggunakan metode penafsiran Alquran yang diajukan oleh Rahman.

${ }^{14}$ Amin Abdullah, "Paradigma Alternatif Pengembangan Ushul Fiqh Dan Dampaknya Pada Fiqh Kontemporer," in Mazhab Yogya: Menggagas Paradigma Ushul Fiqh Kontemporer (Yogyakarta: ArRuzz Press, 2002), 123.
}

secara aplikatif kurang berminat menggali teks Alquran dalam konteks historisnya daripada dalam detail linguistiknya. ${ }^{15}$ Lebih lanjut, Ikhwan membuktikan bahwa Shihab, sangat terpengaruh dengan tokoh modernis Mesir seperti Muhammad Abduh. Bagi Ikhwan, Shihab mencoba menunjukkan hermeneutika kreatif dalam argumentasinya melalui tradisi interpretasi masa lalu dan merangkainya sehingga sesuai dengan kebaharuan masa kini. ${ }^{16}$ Selain Ikhwan dan Pink, Muzayyin juga membahas "Resepsi Heremeneutika Dalam Penafsiran Al-Qur'an oleh M. Quraish Shihab." Menurut Muzayyin, Shihab berada pada posisi tengah, antara kalangan yang kontra hermeneutika secara totalitas dan menerima secara utuh. ${ }^{17}$ Posisi tulisan ini ingin menguji tesis Johanna Pink tersebut dalam kasus ayat-ayat hukum. Selain itu, tulisan ini berbeda dengan artikel Muzayyin, dimana ia lebih fokus dalam menelusuri argumen-argumen yang dikemukakan Shihab dalam menerima hermeneutik, sementara tulisan ini lebih menfokuskan kepada bagaimana Shihab mengaplikasikan hermeneutik dalam kitab tafsirnya, AlMishbah. Di samping itu, tulisan ini juga fokus kepada hermeneutik double movement saja, bukan hermeneutik secara umum, seperti yang terdapat dalam kajian Muzayyin. Penelusuran terhadap hermeneutik ini bertujuan untuk menemukan syarat atau batasan Quraish Shihab dalam menggunakan hermeneutik; kapan dan dalam hal apa dia menggunakan atau menolaknya.

Artikel lain yang berkaitan antara lain adalah "Konsep dan Penerapan Takwil Muhammad Quraish Shihab dalam Tafsir AlMishbah" karya Dedi Junaedi, yang memfokuskan kepada penerapan takwil dalam

\footnotetext{
${ }^{15}$ Munirul Ikhwan, “An Indonesian Initiative to Make the Qur'an Down-to-Earth: Muhammad Quraish Shihab and His School of Exegesis," 2015, http://dx.doi.org/10.17169/refubium-12771, 27.

${ }^{16}$ Ikhwan, 63.

${ }^{17}$ Muzayyin, "Resepsi Hermeneutika Dalam Penafsiran Al-Qur'an Oleh M. Quraish Shihab.”
} 
Tafsir Al-Mishbah ${ }^{18}$ "Nilai-nilai Pendidikan Karakter Perspektif Tafsir Al-Mishbah karya Muhammad Quraish Shihab" oleh Muh Mawangir yang menjelaskan makna nilainilai pendidikan karakter dalam Tafsir AlMishbah;" "Nalar Ijtihad Jilbab Dalam Pandangan M. Quraish Shihab" oleh Atik Wartini yang memfokuskan kepada metode ijtihad yang digunakan Quraish Shihab dalam mengeluarkan hukum tidak wajibnya jilbab; ${ }^{20}$ dan "Dekonstruksi Israiliyat dalam Tafsir AlMishbah" oleh Afrizal Nur yang memfokuskan kepada kemungkinan adanya israiliyyat dalam Tafsir Al-Mishbah. ${ }^{21}$ Artikel lainnya ditulis oleh M. Djidin dan Sahiron Syamsuddin, membahas studi komparasi penafsiran M. Quraish Shihab dan Yudian Wahyudi terhadap ayat khalifah dalam Surah al-Baqarah ayat 30-38. Djidin dan Syamsuddin bersimpulan bahwa motivasi kedua penulis ini berbeda, Shihab menafsirkan keseluruhan Alquran sedangkan Wahyuddin dalam konteks merespon konsep khilafah oleh Hizbut Tahrir Indonesia (HTI). Selain itu, Djidin dan Syamsuddin melihat bahwa prinsip penafsiran Shihab melihat konsep-konsep kunci dari ayat sedangkan Yudian melakukan interpretasi simbolik terhadap ayat. ${ }^{22}$

Kajian ini dilakukan dengan menggunakan metode content analysis. Objek pembahasannya adalah pemikiran tafsir $\mathrm{M}$.

\footnotetext{
${ }^{18}$ Dedi Junaedi, "Konsep dan Penerapan Takwil Muhammad Quraish Shihab dalam Tafsir Al-Mishbah," Wawasan: Jurnal Ilmiah Agama dan Sosial Budaya 2, no. 2 (December 31, 2017): 223-36, https://doi.org/10.15575/jw.v2i2.1645.

${ }^{19}$ Muh Mawangir, "Nilai-Nilai Pendidikan Karakter Perspektif Tafsir Al-Mishbah Karya Muhammad Quraish Shihab," Tadrib 4, no. 1 (July 2, 2018): 163-82, https://doi.org/10.19109/Tadrib.v4i1.1917.

20 Atik Wartini, "Nalar Ijtihad Jilbab Dalam Pandangan M. Quraish Shihab (Kajian Metodologi)," Musãwa Jurnal Studi Gender Dan Islam 13, no. 1 (January 2014): 3, 29-38, https://doi.org/10.14421/musawa.2014.131.29-38.

${ }^{21}$ Afrizal Nur, "Dekonstruksi Isra'iliyyat Dalam Tafsir Al-Mishbah," An-Nida' 39, no. 1 (February 5, 2014): 36-48.

${ }^{22}$ Djidin and Syamsuddin, "Indonesian Interpretation of the Qur'an on Khilāfah.”
}

Quraish Shihab terhadap ayat-ayat hukum yang terdapat dalam Tafsir al-Mishbah, terutama ayat-ayat hukum yang juga dibahas oleh Rahman.

\section{B. PEMBAHASAN}

\section{Hermeneutik Fazlur Rahman: Double Movement (Gerakan Ganda)}

Secara sederhana, Rahman mendiskripsikan hermeneutik double movement dengan memahami Alquran dari situasi sekarang ke masa Alquran diturunkan, dan kembali lagi ke masa kini. ${ }^{23}$ Rahman bermaksud agar teks yang lahir pada masa lalu tetap bisa berbicara pada masa sekarang.

Dalam menggunakan metode ini, seorang mufasir dituntut mengembalikan teks yang akan ditafsirkannya, bergerak terbalik dari situasi sekarang ke masa lampau untuk melihat konteks sosio historisnya dan menemukan prinsip-prinsip ideal moralnya untuk kemudian kembali lagi ke situasi sekarang guna melakukan kontekstualisasi nilai-nilai tersebut. Produk-produk penafsiran harus mengabdi pada nilai ideal moral yang tidak lain adalah prinsip etis Alquran. $^{24}$ Dengan demikian, mufasir seyogiyanya mampu mencari benang merah antara ideal moral dan legal formal. Hal ini dibutuhkan agar terhindar dari penafsiran tekstual yang bisa bertolak belakang dengan nilai moral Alquran. $^{25}$

Aplikasi metode ini tidak hanya membutuhkan pengetahuan tentang sebab turunnya ayat (asbab al-nuzul) dan nasakh, tetapi juga sejarah sosial dan budaya pada masa kenabian dan masa sekarang. Menurut Rahman, Alquran adalah respon terhadap situasi sosio moral Arab pada masa Nabi. Ini dapat diihat dari pernyataan moral dan sosial yang menanggapi masalah-masalah spesifik

\footnotetext{
${ }^{23}$ Fazlur Rahman, Islam Dan Modernitas: Tentang Transformasi Intelektual (Bandung: Pustaka, 2000), 6.

${ }^{24}$ Abdul Mustaqim, Epistemologi Tafsir Kontemporer (Yogyakarta: LkiS, 2010), 154.

${ }^{25}$ Mustaqim, 139.
} 
yang dihadapkan padanya dalam situasi yang konkret pada waktu diturunkan. ${ }^{26}$

Rahman menerapkan teori ini ketika menafsirkan ayat hukum, terutama ayat yang berbicara seputar hukum potong tangan bagi pencuri, riba, warisan bagi perempuan, poligami, dan perbudakan. Ayat memberikan kesan tidak kompromi terhadap gender dan tidak beradaptasi dengan perubahan sosial dewasa ini. Kemudian, Rahman, dengan metode hermeneutiknya, menafsirkan ayatayat ini secara kontekstual.

Sebagai contoh dapat diamati pada ayat waris. Menurut Rahman, dengan melihat kondisi sosio historis Arab ketika ayat turun, akan nampak bagaimana Alquran memberi kewenangan lebih luas terhadap hak waris perempuan, dimana sebelumnya tidak terdapat pada tradisi Arab pra-Islam. ${ }^{27}$ Prinsip tersebut hendaknya diterapkan di era kontemporer sekarang ini. Dengan demikian, terbuka peluang persamaan pembagian warisan anak laki-laki dan perempuan.

Adapun mengenai poligami (QS Al-Nisa[4]: 3), menurut Rahman, perintah untuk bertindak adil terhadap para istri menunjukkan pesan terdalam Alquran, yaitu perintah monogami. Dengan kata lain, ideal moral Alquran pada ayat ini adalah monogami. Untuk memahami ideal moral Alquran, hendaknya dilakukan penelusuran sosiohistoris. Kebolehan poligami muncul sebenarnya terkait dengan kasus wali bagi seorang gadis yatim, dimana ia ingin menikahinya dengan tujuan memakan harta gadis yatim tersebut. Alquran menerima ketentuan hukum untuk beristri lebih dari satu (dua, tiga, atau empat) karena ketidakmungkinan menghapus praktek poligami yang terjadi ketika itu sebagaimana dimaklumi bahwa praktek ini telah mentradisi di kalangan Arab Jahiliyah pra-Islam. Tradisi poligami ini terpelihara hingga kedatangan Islam. Secara tekstual, Alquran terkesan

\footnotetext{
${ }^{26}$ Sibawaihi Sibawaihi, Hermeneutika Alquran Fazlur Rahman (Yogyakarta: Jalasutra, 2007), 5.

${ }^{27}$ Rahman, Islam Dan Modernitas: Tentang Transformasi Intelektual, 20.
}

melegalkan tradisi tersebut. Sebaliknya, pesan moral Alquran sesungguhnya adalah monogami. Rahman menggarisbawahi bahwa ideal moral Alquran hendaknya dapat berkompromi dengan kondisi aktual masyarakat Arab pada abad ke-7. Diketahui bahwa poligami saat itu telah mengakar dalam tradisi mereka dan tidak bisa dihilangkan seketika Alquran diturunkan. $^{28}$

Tentang hukum potong tangan, QS alMaidah [5]: 38, Rahman berpendapat hukuman potong tangan adalah hukum yang sangat mengerikan. Baginya, potong tangan bagi pencuri telah mentradisi di kalangan masyarakat Arab, jauh sebelum Islam datang. Rahman menganggap tradisi ini bukanlah hukum Islam. $^{29}$ Ia menafsirkan faqtha'u aidiyahuma dengan memotong kemampuan pencuri untuk mencuri lagi dan inilah ideal moralnya. Rahman berpendapat, sedianya hukuman dilakukan dengan mempertimbangkan asas kemanusiaan, seperti kurungan penjara dalam waktu relatif lama atau denda seberat-beratnya. ${ }^{30}$

Perubahan sosial membolehkan aturan yang telah ada pada masa lampau untuk diadaptasi sehinga sesuai dengan zaman sekarang selama tidak melanggar prinsipprinsip umum. ${ }^{31}$ Universalitas Alquran terdapat pada aspek moral atau value yang mendasarinya, bukan pada ketentuan harfiah atau lafaznya. ${ }^{32}$ Bersikukuh dalam implementasi tekstual aturan Alquran dan menafikan perubahan sosial yang realistik sama saja dengan dengan mengabaikan tujuan-tujuan moralnya. ${ }^{33}$

\footnotetext{
${ }^{28}$ Sibawaihi, Hermeneutika Alquran Fazlur Rahman, 76-77.

${ }^{29}$ Sibawaihi, 81.

${ }^{30}$ Sibawaihi.

${ }^{31}$ Rahman, Islam Dan Modernitas: Tentang Transformasi Intelektual, 9.

${ }^{32}$ Sibawaihi, Hermeneutika Alquran Fazlur Rahman, 62.

${ }^{33}$ Rahman, Islam Dan Modernitas: Tentang Transformasi Intelektual, 21.
} 


\section{Metode Double Movement dalam Tafsir al Mishbah}

Sub bahasan ini tidak bermaksud mengulas semua hermeneutik Rahman yang ada dalam Tafsir al-Mishbah, melainkan terfokus kepada QS Al-Nisā [4]: 3 tentang poligami, QS AlNisā [4]: 11 tentang warisan, QS al-Mäidah [5]: 38 hukum potong tangan terhadap pelaku mencuri, dan QS al-Mäidah [5]: 5 tentang menikahi perempuan Ahl Kitab. Pemilihan ini karena Rahman juga mengupas tiga ayat pertama dalam karyanya sedangkan ayat terakhir tidak dibahas oleh Rahman, namun Shihab menggunakan double movement dalam menafsirkannya sehingga penulis mengupasnya dalam artikel ini.

a. Penafsiran ayat poligami (QS al-Nisa[4]: 3)

Dalam QS. al-Nisa[4] 3, Allah berfirman:

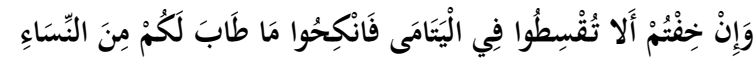

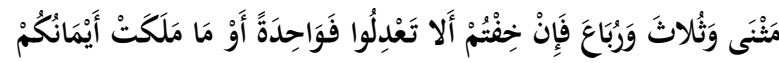

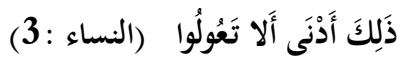

Dan jika kamu takut tidak akan dapat berlaku adil terhadap (hak-hak) perempuan yang yatim (bilamana kamu mengawininya), maka kawinilah wanitawanita (lain) yang kamu senangi: dua, tiga atau empat. kemudian jika kamu takut tidak akan dapat berlaku adil, maka (kawinilah) seorang saja, atau budak-budak yang kamu miliki. yang demikian itu adalah lebih dekat kepada tidak berbuat aniaya (QS Al-Nisa [4]: 3).

Shihab memulai penafsiran ayat tentang poligami di atas dengan terlebih dahulu mengungkap konteks historis ayat (asbāb al$n u z \bar{u} l)$ tersebut. Berdasarkan informasi dari Aisyah diperoleh keterangan bahwa ayat tersebut berkenaan dengan seorang anak yatim yang dipelihara oleh walinya. Harta anak yatim tersebut masih tergabung dengan harta walinya. Wali anak yatim tersebut menyukai kecantikan anak asuhannya serta harta yang dimilikinya. Kemudian, ia berkeinginan menikahinya tanpa mahar yang sewajarnya. Ayat ini secara tegas melarang wali tersebut mengawini anak-anak yatim dengan maksud menginginkan harta dan kecantikannya.
Penyebutan kebolehan berpoligami baik dua, tiga, maupun empat pada ayat tersebut guna menuntut berbuat adil kepada anak yatim tersebut. ${ }^{34}$ Dengan kata lain, poligami dalam ayat ini bukanlah anjuran. Hakekat poligami dalam ayat tersebut adalah solusi dari kondisi darurat yang membutuhkan, seperti emergency exit di pesawat terbang, dan memenuhi syarat bisa berlaku adil. ${ }^{35}$ Jika demikian, makalah kedudukan poligami adalah sebagai rukhsah atau pintu darurat. Dapat dikatakan bahwa prinsip pernikahan Islam menurut Shihab adalah monogomi.

Selanjutnya Shihab menegaskan bahwa poligami telah dikenal dan menjadi tradisi masyarakat pra-Islam sebelum turun ayat ini. $^{36}$ Dalam karyanya yang lain, Shihab memulai pembahasan QS al-Nisa- [4]: 3 ini dengan terlebih dahulu mengemukakan kondisi sosiohistorisnya. Ia mengungkap bahwa tradisi poligami telah ada sebelum Alquran turun. Bahkan kebiasaan poligami pra-Islam hingga membolehkan laki-laki mempunyai isteri tanpa batas. ${ }^{37}$ Shihab menegaskan bahwa bukanlah membuat aturan baru tentang poligami karena prakteknya telah ada dalam syariat agama dan adat istiadat masyarakat sebelum turunnya ayat ini. Selain itu, ayat ini tidak juga menganjurkan apalagi mewajibkan poligami. Kebolehan poligami dalam ayat ini karena emergency, dan itu pun bisa dilakukan dengan rambu-rambu yang ketat. Ia menegaskan bahwa Alquran tidak membuka kran untuk berpoligami, melainkan sebaliknya membatasinya. ${ }^{38}$

${ }^{34}$ M. Quraish Shihab, Tafsir Al-Mishbah Pesan, Kesan, Dan Keserasian Al-Quran, vol. 2, 15 vols. (Jakarta: Lentera Hati, 2000), 324.

${ }^{35}$ M. Quraish Shihab, Perempuan: Dari Cinta Sampai Seks, Dari Nikah Mut'ah Sampai Nikah Sunnah, Dari Bias Lama Sampai Bias Baru (Jakarta: Lentera Hati, 2006), 180.

${ }^{36}$ Shihab, Tafsir Al-Mishbah Pesan, Kesan, Dan Keserasian Al-Quran, 324.

${ }^{37}$ Shihab, Perempuan: Dari Cinta Sampai Seks, Dari Nikah Mut'ah Sampai Nikah Sunnah, Dari Bias Lama Sampai Bias Baru, 159-161.

${ }^{38}$ Shihab, 165. 
Penjelasan Shihab di atas menunjukkan prinsip monogami dalam Qs Al-Nisā [4]: 34 ini. Ia menggunakan konteks historis ayat (asbāb al-nuzūl) guna menarik perhatian pembaca sebelum menafsirkan ayat. Jauh dari itu, ia mengungkap sejarah sosial dan budaya poligami sebelum periode kenabian Muhammad Saw. Apa yang dilakukan oleh Shihab ini sama dengan metode double movement Rahman.

\section{b. Penafsiran ayat waris (Al-Nisā [4]: 11)}

Alquran secara redaksional ayat menetapkan bahwa bagian anak perempuan setengah dari bagian anak laki-laki, sebagaimana yang terdapat pada Qs alNisa,-[4]: 11

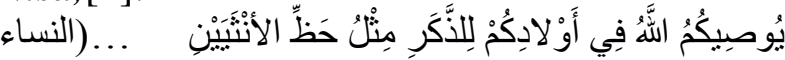

Allah mensyari'atkan bagimu tentang (pembagian pusaka untuk) anak-anakmu. Yaitu : bahagian seorang anak lelaki sama dengan bahagian dua orang anak perempuan.... (QS al-Nisä,[4]:11)

Menurut Shihab, ketentuan warisan dua berbanding satu antara anak laki-laki dan perempuan merupakan ketentuan yang sudah final. Artinya tidak ada ruang ijtihad untuk pembagian warisan pada ayat ini karena berdasarkan redaksional ayat. Kemudian Allah melanjutkan uraiannya bahwa:

Orang tuamu dan anak-anakmu, kamu tidak mengetahui siapa di antara mereka yang lebih dekat (banyak) manfaatnya bagimu. ini adalah ketetapan dari Allah. Sesungguhnya Allah Maha mengetahui lagi Maha Bijaksana.

Selanjutnya al-Nisā̄QS [4]: 13-14, Allah menegaskan:

(Hukum-hukum tersebut) itu adalah ketentuan-ketentuan dari Allah.

Barangsiapa taat kepada Allah dan RasulNya, niscaya Allah memasukkannya kedalam syurga yang mengalir didalamnya sungai-sungai, sedang mereka kekal di dalamnya; dan Itulah kemenangan yang besar. Dan barangsiapa yang mendurhakai Allah dan Rasul-Nya dan melanggar
ketentuan-ketentuan-Nya, niscaya Allah memasukkannya ke dalam api neraka sedang ia kekal di dalamnya; dan baginya siksa yang menghinakan.

Dalam uraiannya Shihab mengungkap bahwa adanya perubahan sosial saat ini dimana perempuan ikut mencari nafkah tidak serta merta dapat dijadikan argumentasi mengganti ketenuan Allah dua berbanding satu dalam ayat tersebut. Alasannya adalah kaum hawa tidak selamanya bisa bekerja mencari nafkah sepanjang waktu. Misalnya dalam masa kehamilan, melahirkan anak, dan mengasuhnya. Dalam kondisi ini, perempuan menjadi lemah karena konsentrasi menyusui dan memelihara anaknya.

Untuk menjawab anggapan adanya ketidakadilan gender pada ayat ini, Shihab menjelaskan bahwa komposisi laki-laki lebih banyak dari perempuan karena faktor kewajiban memberi nafkah terletak di pundak laki-laki karena ia adalah kepala keluarga. Shihab menegaskan bahwa bagian laki-laki dua kalipat ini sebenarnya rasionalisasi dari satu untuk dirinya dan satu lagi untuk isterinya. Sementara perempuan jika telah menikah, kebutuhan finansialnya ditanggung oleh suaminya dan bahagian warisannya yang satu bisa didepositokannya. Jadi dua bagian yang diperoleh anak laki-laki harus dibagi dua, sedangkan apa yang dimiliki oleh perempuan tidak digunakannya sama sekali. Dengan demikian, dalam soal waris mewarisi, Shihab menegaskan bahwa meskipun secara redaksional ayat komposisi laki-laki lebih banyak akan tetapi keberpihakan Allah kepada perempuan lebih berat daripada keberpihakannya kepada laki-laki. ${ }^{39}$

Berbeda dengan Shihab, Rahman justru berpendapat ketentuan warisan ini belum final. Anak perempuan berkemungkinan untuk mendapat warisan yang sama dengan anak laki-laki. Rahman menggunakan double movement mengungkap bahwa Alquran pada intinya sedang memperluas hak waris

\footnotetext{
${ }^{39}$ Shihab, 261-263.
} 
terhadap perempuan. Pembagian ini menurut Rahman tidak dimiliki oleh perempuan Arab pra-Islam. Maka ideal moral Alquran, memperluas hak waris anak perempuan, inilah yang hendak dituju Alquran untuk bisa diterapkan pada masa sekarang. Dengan demikian, Rahman membuka peluang persamaan pembagian warisan antara anak laki-laki dan perempuan.

Pada ayat warisan ini, Shihab tidak menggunakan metode penafsiran seperti metode double movement Rahman. Shihab hanya merujuk kepada teks ayat tanpa melirik sejarah sosial masyarakat Arab ketika ayat turun. Berdasarkan hal ini ia menyimpulkan bahwa perubahan perempuan pada konteks sekarang tidak berpengaruh kepada ketentuan warisan yang sudah ditetapkan.

\section{c. Penafsiran hukuman bagi pencuri (QS al-Maidah [5] : 38)}

Allah menetapkan bahwa hukuman bagi pencuri adalah potong tangan, sebagaimana yang terdapat dalam QS al-Mäidah [5]: 38:

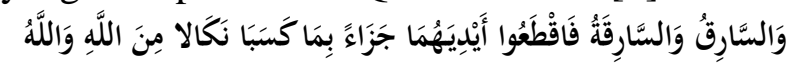

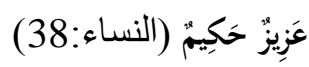

Mengenai hukuman potong tangan bagi pencuri, dengan merujuk kepada hadis, Shihab mengatakan bahwa potong tangan tidak diberlakukan kecuali pada pencurian barang berharga. Mayoritas ulama, menurut Shihab, berpendapat berdasarkan sekian banyak riwayat bahwa tidak ada pemotongan tangan pencuri jika yang dicuri tidak mencapai seperempat dinar. Harga satu dinar pada masa Nabi adalah 12 dirham. Artinya bahwa seperempat dinar sama dengan 3 dirham. Shihab menjelaskan bahwa satu dirham mencukupi untuk kebutuhan makan satu keluarga berdasarkan hadis Nabi yang memberi seorang sahabat satu dirham sambil berkata "Belilah makanan untukmu dan keluargamu." Menurut asy Sya'rawi, pada masa sekarang, yakni tahun 1999 M ketika ia menulis tafsirnya, satu dirham senilai lebih dari 20 Pound Mesir atau sekitar tujuh dolar Amerika. Dengan demikian kini tiga dirham atau seperempat dinar sekitar 21 dolar Amerika. ${ }^{40}$

Selain berdasarkan harga barang curian, penentuan potong tangan juga dipengaruhi oleh aspek lain yang meringankan. Shihab mengungkap kisah Umar yang tidak menerapkan sanksi potong tangan bagi pencuri. Alasannya adalah ketika itu sedang terjadi krisis atau paceklik. Umar juga tidak memotong tangan kepada sekelompok pekerja yang mencuri seekor unta. Alasannya karena majikannya tidak memberikan mereka upah yang wajar. Umar bahkan memberikan hukuman kepada sang majikan bernama Ibn Hațib ibn Abi al-Ta'ah. Ia diwajibkan membayar dua kali lipat harga unta yang dicuri tersebut kepada pemilik unta. Shihab menganalogikan seandainya ada pencuri memasuki toko atau rumah yang tidak dikunci dan terbuka lebar, bila dimasuki pencuri, maka pencuri dapat dibebaskan dari hukuman potong tangan. Alasan Shihab adalah karena pemiliknya memberi peluang bagi pencuri untuk melakukan kejahatan. ${ }^{41}$

Shihab menegaskan hal ini bukan berarti si pencuri tidak dijatuhi hukuman sama sekali, tapi diganti dengan hukuman ta'zir, yaitu hukuman yang lebih ringan dari hukuman yang sudah ditetapkan (potong tangan) bila bukti pelanggaran cukup kuat. Ta'zir dapat berupa hukuman penjara atau apa saja yang dinilai wajar oleh yang berwenang. ${ }^{42}$

Penjelasan Shihab ini menunjukkan bahwa menurut dia hukuman potong tangan wajib dilaksanakan bagi pelaku pencurian. Namun berapa nilai pencurian dan bagaimana kondisi pencurian yang mewajibkan potong tangan, maka itu menjadi ranah ijtihad. Pada kenyataannya para fuqaha memang berbeda pendapat dalam menentukan nisab pencurian yang dijatuhi hukuman potong tangan.

\footnotetext{
${ }^{40}$ Shihab, vol. 3, 15 vols, Tafsir Al-Mishbah Pesan, Kesan, Dan Keserasian Al-Quran, 88. Jika 1 Dolar sama dengan 14 ribu, maka $1 / 4$ dinar/21 dolar sama dengan Rp 294 ribu

${ }^{41}$ Shihab, 87-88.

${ }^{42}$ Shihab.
} 
Hukuman potong tangan merupakan hukuman maksimal. Jika tidak dijatuhi hukuman maksimal, maka pelaku bisa dijatuhi hukuman ta'zir.

Shihab menerima pendapat potong tangan sebagai batas hukuman maksimal bagi pencuri. Hal ini memungkinkan bagi hakim menjatuhkan hukuman yang lebih ringan dibandingkan potong tangan. Shihab menjelaskan bahwa meskipun tidak diisyarakat dalam redaksional ayat, namun hakim bisa menetapkannya jika ditemukan alasan yang meringankan si pencuri. Shihab tidak menyebutkan referensinya dalam terhadap pendapat tersebut, namun jika ditelusuri, pendapat ini tidak jauh berbeda dengan pendapat Syahrur dengan teori batasnya. ${ }^{43}$

Shihab menolak pemaknaan majazi terhadap potongan faqtha' $u$ aidiyahuma, yang dimaknai dengan melumpuhkan kemampuan sebagaimana ditafsirkan secara hermeneutika oleh Rahman dengan memenjarakannya. Alasan Shihab karena pendapat melumpuhkan tersebut tidak sesuai dengan praktek Nabi Saw. ${ }^{44}$ Berdasarkan uraian di atas, Shihab menolak penggunaan metode double movement dalam menafsirkan ayat tentang hukuman potong tangan bagi pencuri.

\section{d. Penafsiran ayat tentang menikahi perempuan Ahli Kitab (QS al-Maidah [5] :5)}

Shihab memaparkan bahwa pernikahan bertujuan mewujudkan sakinah dan mawaddah dalam rumah tangga. Untuk itu, pernikahan dapat dikatakan langgeng jika terdapat kesesuaian pandangan hidup antara suami istri. Jangankan perbedaan agama, perbedaan budaya bahkan tingkat pendidikan pun tidak jarang menimbulkan kesalahpahaman dan kegagalan perkawinan. ${ }^{45}$

${ }^{43}$ Sahiron Syamsuddin, Hermeneutika Alquran Mazhab Yogya (Yogyakarta: Penerbit Islamika, 2003), 262.

${ }^{44}$ Shihab, vol. 3, 15 vols, Tafsir Al-Mishbah Pesan, Kesan, Dan Keserasian Al-Quran, 88.

${ }^{45}$ Shihab, 29.
Pada awalnya, Alquran melarang perkawinan lintas agama berdasarkan QS alBaqarah [2]: 221. Menurut Shihab, QS alMaidah [5]: 5 tentang kebolehan laki-laki Muslim menikahi Ahl Kitab merupakan jalan keluar kebutuhan mendesak ketika itu. Shihab menegaskan bahwa ketika itu, laki-laki muslim banyak yang melakukan jihad untuk berdakwah. Dengan demikian, intensitas mereka meninggalkan anak isterinya cukup tinggi. Perempuan muslimah tidak diperkenankan menikah dengan laki-laki nonmuslim. Ketidakbolehan ini berlaku umum, baik terhadap laki-laki ahli kitab maupun musyrik. Argumen Shihab bahwa laki-laki seharusnya menjadi pemimpin dalam keluarga, sehingga dikhawatirkan akan terjadi pemaksaan beragama karena ia tidak meyakini agama isterinya. ${ }^{46}$

Shihab menilai konteks sosiohistoris turunya ayat (QS al-Mäidah [5]: 5) dalam konteks menghadirkan pengecualian, yaitu kebolehan laki-laki muslim menikahi perempuan ahli kitab. Ayat tersebut turun pada saat umat Islam telah memiliki tuntunan agama yang sempurna, sehingga non Muslim ketika itu dalam kondisi lemah dan putus asa mengalahkan pengikut Nabi Muhammad agar mereka kembali ke agama nenek moyang mereka. Bagi Shihab, kebolehan menikahi wanita Ahl Kitab tersebut menandakan Islam dalam kondisi sempurna dan keluhuran budi pekerti yang diajarkan suami muslim terhadap isteri Ahl Kitab tanpa memaksa mereka beralih agama menjadi muslim. ${ }^{47}$

Aplikasi ayat ini dimasa sekarang, seharusnya tidak mengabaikan sosiohistoris turunnya ayat serta maksud umum ayat tersebut. Dalam hal ini, Shihab tidak membolehkan hubungan perkawinan laki-laki muslim dengan perempuan Ahli Kitab jika laki-laki muslim tersebut dikhawatirkan tidak bisa menghadirkan Islam yang sempurna dalam kesehariannya setelah berumah tangga

\footnotetext{
${ }^{46}$ Shihab, 30.

${ }^{47}$ Shihab.
} 
apalagi akan dipengaruhi oleh isterinya sehingga akan pindah keyakinan. ${ }^{48}$

Penafsiran kontekstual Alquran yang diusung double movement Rahman mementingkan penelusuran aspek sosiohistoris ketika Alquran diturunkan, seperti asbab alnuzul, makky madany, dan juga kondisi sosial masyarakat Arab secara keseluruhan sebagai penerima Alquran pada masa itu. Jauh sebelum Rahman, para mufasir sudah menggunakan kajian-kajian ini dalam penafsiran mereka. Namun terdapat perbedaan mendasar antara mufasir dengan Rahman.

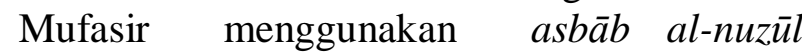
sebatas pelengkap informasi yang dapat menambah penjelasan ayat dan cenderung mengabaikan motif, pesan moral, nilai atau prinsip umum dari peristiwa yang melatarinya. Sebaliknya double movement, justru menggunakan asbab al-nuzul , makky madany untuk mengambil pesan moral, motif, nilai atau prinsip umum dari peristiwa tersebut untuk diberlakukan pada setiap waktu dan tempat. $^{49}$

Merujuk kepada hermeneutika double movement Rahman, mufasir dalam memaknai redaksi ayat, melakukan gerakan mulai dari situasi yang dihadapinya kembali kepada konteks sosiohistoris saat ayat diturunkan untuk kemudian menemukan gagasan dasar atau ideal moralnya dan akhirnya kembali ke masa sekarang untuk mengontekstualisasi prinsip dasar tersebut di masa sekarang. Hal ini yang dilakukan oleh Shihab ketika membolehkan pernikahan laki-laki muslim dengan perempuan ahli kitab (QS al-Mäidah [5]: 5). Shihab membacanya dengan bergerak ke masa ketika ayat ini diturunkan untuk melihat konteks sosiohistoris pada masa itu. Hal ini dilakukan untuk menemukan prinsip dasar atau ideal moral nya, yaitu bahwa pada masa ketika ayat ini turun, laki-laki muslim

\footnotetext{
${ }^{48}$ Shihab.

${ }^{49}$ Irma Riyani and Yeni Huriani, "Reinterpretasi Asbāb Al-Nuzūl Bagi Penafsiran Alquran," Wawasan: Jurnal Ilmiah Agama Dan Sosial Budaya 2, no. 1 (June 30 , 2017): 113-30,
}

berada pada taraf keimanan yang sangat kuat dan mampu menunjukkan kesempurnaaannya Islam dalam kehidupannya. Oleh karena itu prinsip dasar inilah yang mestinya diperhatikan pada masa sekarang ketika membaca ayat yang membolehkan pernikahan laki-laki muslim dengan perempuan Ahli Kitab.

\section{e. Analisis Double Movements dalam Tafsir Al-Mishbah}

Melalui penelusuran terhadap penafsiran empat ayat hukum yang dibahas di atas, ditemukan bahwa Shihab menggunakan metode hermeneutik double movement dalam kitab Tafsir Al-Mishbah. Metode double movement yang digunakan Rahman untuk menafsirkan ayat tentang poligami, juga digunakan oleh Shihab. Di samping itu, Shihab juga memperluas penggunaannya terhadap ayat lain yang tidak dibahas oleh Rahman, yaitu ayat tentang bolehnya laki-laki muslim menikahi perempuan ahli kitab. Akan tetapi meskipun mengaplikasikan double movement pada ayat poligami, ia menolak mengaplikasikannya pada ayat waris dan ayat hukuman potong tangan bagi pencuri.

Data membuktikan bahwa ia (Shihab) tidak menolak double movement secara totalitas dan tidak pula menerimanya secara utuh. Penerimaan Shihab dengan alasan bahwa tidak semua aliran hermeneutika tersebut keliru, karena ada juga yang yang bisa dimanfaatkan untuk memperkaya perspektif dalam penafsiran Alquran. Hanya saja, perlu berhati-hati terhadap kemungkinan kekeliruan dalam aplikasinya. ${ }^{50}$

Empat contoh di atas menunjukkan bahwa Shihab melakukan dua hal berbeda, mengabaikan redaksi kitab suci Alquran serta tidak mengabaikannya. Misalnya ayat poligami, Shihab tidak mengabaikan redaksi Alquran. Namun, ia sejalan dengan pandangan Rahman dengan pertimbangan sosiohistoris sebelum masuknya Islam ditambah lagi

${ }^{50}$ M. Quraish Shihab, Kaidah Tafsir Syarat, Ketentuan, Dan Aturan Yang Patut Anda Ketahui Dalam Memahami Ayat-Ayat al-Qur'an (Jakarta: Lentera Hati, 2013), 427. 
dengan argumentasi dari redaksi Alquran lainnya yang menegaskan bahwa jika ada kekhawatiran tidak sanggup berbuat adil terhadap para isteri maka hendaklah beristeri satu orang saja karena ketidakadilan tersebut akan mendorong perbuatan aniaya. Jika ayat dimaknai tanpa melihat konteks sosiohistoris sebelum Islam (hermeneutika), tentunya isyarat nas Alquran tersebut dimaknai untuk lebih memilih poligami, bukan monogami. Di sinilah peran double movement dalam dalam konteks penafsiran ayat ini, membantu mufasir memperkaya perspektif ketika menafsirkan Alquran.

Lain halnya dengan potong tangan bagi pencuri. Ia tidak sejalan dengan Rahman, dengan memaknai potong tangan dengan melumpuhkan kemampuan pencuri untuk mencuri lagi sebagai efek jera baginya. Tentunya, penafsiran Rahman dalam kasus ini menafikan keberadaan nas Alquran. Mustaqim dalam riset doktoralnya mengungkapkan argument bahwa efek dari perspektif sosiohistoris adalah mengesankan "desakralisasi teks". Baginya, sakralitas ini terletak pada nilai ideal moral, adapun teks Alquran akan dalam hal tertentu dapat diketepikan. Mustaqim menekankan bahwa dimensi terpenting untuk disakralkan adalah substansi nilai ideal moral. Sifat dimensi ini universal. Dengan demikian jebakan makna tekstual Alquran dapat dihindari. Dalam hal pencuri sekarang ini dilakukan tidak dengan tangan, akan tetapi menggunakan kedudukan atau kekuasaan. Untuk itu, pencuri dimaksud tidak mesti dipotong tangannya. Ideal moralnya adalah penerapan rasa keadilan dengan adanya unsur jera bagi pencuri, salah satu contohnya adalah penjara seumur hidup. ${ }^{51}$

Wahid juga dalam karyanya memberikan penegasan yang sama, bahwa penekanan terhadap makna kontekstual ayat akan sesuai dengan prinsip Alquran beradaptasi dengan perubahan zaman. Hasil yang diperoleh bahwa interpretasi ulang terhadap Alquran

\footnotetext{
${ }^{51}$ Mustaqim, Epistemologi Tafsir Kontemporer, 301-302.
}

menghasilkan pemaknaan substansial terhadap Alquran. $^{52}$

Ijtihad terhadap ayat potong tangan bagi pencuri tidak dimaknai penghapusan hukuman tersebut karena teksnya tetap ada dalam Alquran. Akan tetapi bisa diganti dengan hukuman maksimal. Dengan demikian, membuka ruang adanya hukuman-hukuman jenis lain seperti penjara dan lainnya. Maka, memahami hukuman potong tangan sebagai hukuman maksimal, seperti yang dikemukakan Syahrur dan disetujui atau diterima oleh Quraish Shihab, tidak mengabaikan teks dan tidak menghapus hukuman yang sudah ditetapkan Alquran.

Tidaklah berlebihan jika Shihab memaknai term sāriq (pencuri) dalam ayat dengan makna umum, terhadap siapa saja yang mencuri. Di sinilah posisi ijtihad terhadap penafsiran ayat tersebut masih ada. Pada sisi lain, ditemukan hadis yang menjelaskan tentang kadar atau nisab barang curian yang bervariasi. Dengan demikian, memahami hukuman potong tangan sebagai hukuman maksimal tidak membawa kepada pengabaian teks Alquran.

Shihab tidak menerima penggunaan double movement terhadap ayat kewarisan perempuan. Metode double movement, Rahman membuka peluang persamaan pembagian anak laki-laki dan perempuan. Sementara menurut Shihab, warisan bagi kaum hawa sudah final adanya dan tidak terbuka peluang ijtihad. Shihab berargumen karena tidak seyogyanya redaksi tektual ayat dicerabut dari Alquran untuk mendapatkan makna lain seperti dalam kasus waris perempuan. Karena itu, kalimat لِلذَّكَرِ مِثْلُ حَظِّ الأنتَْيَيْنِ آبَأُكُمْ

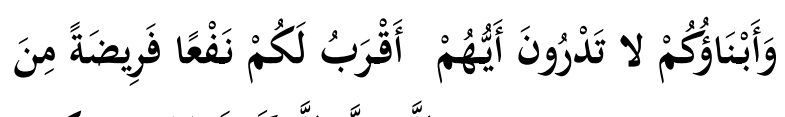
اللَّهِ إِنَّ اللَّهَ كَانَ عَلِيمًا حَكِيمًا dalam ayat 13 dan 14 sebelumnya.

\footnotetext{
${ }^{52}$ Ramli Abdul Wahid, Ulumul Quran (Jakarta: PT Raja Grafindo Persada, 2002), 89.
} 
Selain itu, penggunaan term al-żakar pada ayat sebagaimana diungkap oleh Umar, menekankan kepada jenis kelamin atau berkonotasi biologis. Lain halnya dengan alrijāl yang berkonotasi sifat lelaki (maskulinitas). ${ }^{53}$ Jika perbedaan makna antara dua kata ini bisa diterima, maka pembagian laki-laki dan perempuan penekanannya lebih kepada biologis yang tidak akan berubah dengan perkembangan zaman, dan bukan kepada jender yang bisa berubah sesuai dengan perkembangan tempat dan zaman.

Selanjutnya Shihab terlihat menggunakan metode double movement dalam menafsirkan QS al-Mäidah [5]: 5, dimana Rahman tidak mengupasnya sama sekali. Indikasi ini menandakan bahwa Shihab menerima double movement sebagai salah satu metode dalam menafsirkan Alquran, bahkan lebih jauh lagi, memperluas penggunaannya pada ayat-ayat lain yang tidak dibahas oleh Rahman.

Terhadap ayat ini, Shihab menetapkan syarat izin menikahi perempuan ahli kitab, yaitu laki-laki muslim yang memiliki kesempurnaan dalam keislamannya. Syarat ini tidak ada dalam teks ayat akan tetapi diperoleh dengan double movement, kajian sosiohistoris ketika ayat turun. Dalam konteks ini, Shihab mempersempit peluang kebolehan menikahi perempuan Ahl Kitab. Penerapan ini menandakan bahwa ia menggunakan hermeneutika untuk mempersempit peluang nikah beda agama tersebut.

Shihab tidak secara spesifik menyebut Rahman serta metode double movement dalam tafsir. Namun, dalam kasus-kasus tertentu ia mengaplikasikan metode Rahman, bahkan memperluas penggunaannya dalam ayat yang tidak dibahas oleh Rahman. Hal ini menunjukkan bahwa Shihab menerima hermeneutik double movement sebagai sebuah metode untuk menafsirkan Alquran dengan batasan tertentu. Menafikan batasan ini berpotensi kepada kesalahan dalam penerapan hermeneutika.

\footnotetext{
${ }^{53}$ Nasaruddin Umar, Argumen Kesetaraan Gender Perspektif Alquran (Jakarta: Paramadina, 1999), 146.
}

\section{KESIMPULAN}

Uraian di atas membuktikan bahwa Shihab menerima serta menerapkan hermeneutik double movement sebagai sebuah metode untuk menafsirkan Alquran, seperti dalam kasus QS. Al-Nisā [4]: 3) dan (QS Al-Mäidah [5]: 5) tentang poligami dan nikah beda agama. Namun ia memberikan rambu dalam penerapannya. Rambu tersebut bahwa mufasir hendaknya tidak menafikan keberadaan redaksi ayat, tidak menghapus aspek hukum yang terkandung dalam Alquran, dan memerhatikan ayat secara holistik. Shihab menolak penggunaan hermeneutik dalam menafsirkan Alquran, jika batasan-batasan tersebut diabaikan. Hal ini terlihat ketika ia menafsirkan QS Al-Nisā [4]: 11 dan QS alMaidah [5]: 39 tentang warisan dan hukuman potong tangan.

\section{DAFTAR PUSTAKA}

Abdullah, Amin. "Paradigma Alternatif Pengembangan Ushul Fiqh Dan Dampaknya Pada Fiqh Kontemporer." In Mazhab Yogya: Menggagas Paradigma Ushul Fiqh Kontemporer. Yogyakarta: ArRuzz Press, 2002.

Djidin, M., and Sahiron Syamsuddin. 'Indonesian Interpretation of the Qur'an on Khilāfah: The Case of Quraish Shihab and Yudian Wahyudi on Qur'an, 2: 30-38." AlJami'ah: Journal of Islamic Studies 57, no. 1 (November 26, 2019): 143-66. https://doi.org/10.14421/ajis.2019.571.\%p.

Federspiel, Howard M. Kajian Al-Quran Di Indonesia: Dari Mahmud Yunus Hingga Quraish Shihab. Bandung: Mizan, 1996.

Husaini, Adian. Hermeneutika Dan Tafsir Alquran. Jakarta: Gema Insani, 2007.

Ikhwan, Munirul. "An Indonesian Initiative to Make the Qur'an Down-to-Earth: Muhammad Quraish Shihab and His School of Exegesis," 2015. http://dx.doi.org/10.17169/refubium-12771. Iqbal, Muhammad. Etika Politik Qurani, Penafsiran Quraish Shihab Terhadap AyatAyat Kekuasaan. Medan: IAIN Press, n.d.

Junaedi, Dedi. "Konsep dan Penerapan Takwil Muhammad Quraish Shihab dalam Tafsir 
Al-Mishbah." Wawasan: Jurnal Ilmiah Agama dan Sosial Budaya 2, no. 2 (December 31, 2017): 223-36. https://doi.org/10.15575/jw.v2i2.1645.

Malik, Rif'atul Khoiriah. "Hermeneutika AlQur'an Dan Debat Tafsir Modern: Implementasinya Dengan Masa Kini." ATTURAS: Jurnal Studi Keislaman 6, no. 1 (August 19, 2019): 56-76. https://doi.org/10.33650/at-turas.v6i1.583.

Mawangir, Muh. "Nilai-Nilai Pendidikan Karakter Perspektif Tafsir Al-Mishbah Karya Muhammad Quraish Shihab." Tadrib 4, no. 1 (July 2, 2018): 163-82. https://doi.org/10.19109/Tadrib.v4i1.1917.

Mustaqim, Abdul. Epistemologi Tafsir Kontemporer. Yogyakarta: LkiS, 2010.

Muzayyin, Muzayyin. "Resepsi Hermeneutika Dalam Penafsiran Al-Qur'an Oleh M. Quraish Shihab: Upaya Negosiasi Antara Hermeneutika dan Tafsir al-Qur'anuntuk Menemukan Titik Persamaan dan Perbedaan." Nun: Jurnal Studi Alquran dan Tafsir di Nusantara 1, no. 1 (December 28 , 2015). https://doi.org/10.32459/nun.v1i1.11.

Nur, Afrizal. "Dekonstruksi Isra'iliyyat Dalam Tafsir Al-Mishbah." An-Nida' 39, no. 1 (February 5, 2014): 36-48.

Rahman, Fazlur. Islam Dan Modernitas: Tentang Transformasi Intelektual. Bandung: Pustaka, 2000.

Reflita, Reflita. "Kontroversi Hermeneutika Sebagai Manhaj Tafsir (Menimbang Penggunaan Hermeneutika dalam Penafsiran al-Qur'an)." Jurnal Ushuluddin 24, no. 2 (December 10, 2016): 135-49. https://doi.org/10.24014/jush.v24i2.1625.

Riyani, Irma, and Yeni Huriani. "Reinterpretasi Asbāb Al-Nuzūl Bagi Penafsiran Alquran." Wawasan: Jurnal Ilmiah Agama Dan Sosial Budaya 2, no. 1 (June 30, 2017): 113-30. https://doi.org/10.15575/jw.v2i1.863.

Saeed, Abdullah. Paradigma, Prinsip Dan Metode Penafsiran Kontekstualis Atas AlQur'an. Yogyakarta: Baitul Hikmah Press, 2015.

Shihab, M. Quraish. Kaidah Tafsir Syarat,
Ketentuan, Dan Aturan Yang Patut Anda Ketahui Dalam Memahami Ayat-Ayat alQur'an. Jakarta: Lentera Hati, 2013.

- Perempuan: Dari Cinta Sampai Seks, Dari Nikah Mut'ah Sampai Nikah Sunnah, Dari Bias Lama Sampai Bias Baru. Jakarta: Lentera Hati, 2006.

—. Tafsir Al-Mishbah Pesan, Kesan, Dan Keserasian Al-Quran. Vol. 1. 15 vols. Jakarta: Lentera Hati, 2000.

Sibawaihi, Sibawaihi. Hermeneutika Alquran Fazlur Rahman. Yogyakarta: Jalasutra, 2007.

Syamsuddin, Sahiron. Hermeneutika Alquran Mazhab Yogya. Yogyakarta: Penerbit Islamika, 2003.

- "Hermeneutika Jorge J. E. Gracia Dan Kemungkinannya Dalam Pengembangan Studi Dan Penafsiran AlQur'an." In Upaya Integrasi Hermeneutika Dalam Kajian Qur'an Dan Hadis, Teori Dan Aplikasi. Yogyakarta: Lembaga Penelitian UIN Sunan Kalijaga, 2011.

Umar, Nasaruddin. Argumen Kesetaraan Gender Perspektif Alquran. Jakarta: Paramadina, 1999.

Wadud Muhsin, Amina. Wanita Di Dalam Alquran. Bandung: Pustaka, 1994.

Wahid, Ramli Abdul. Ulumul Quran. Jakarta: PT Raja Grafindo Persada, 2002.

Wartini, Atik. "Nalar Ijtihad Jilbab Dalam Pandangan M. Quraish Shihab (Kajian Metodologi)." Musãwa Jurnal Studi Gender Dan Islam 13, no. 1 (January 3, 2014): 29-38. https://doi.org/10.14421/musawa.2014.131. 29-38. 